\title{
The first report of multidrug resistance in gastrointestinal nematodes in goat population in Poland
}

\author{
Marcin Mickiewicz', Michał Czopowicz ${ }^{1 *}$ DD, Ewelina Kawecka-Grochocka², Agata Moroz ${ }^{1}$, Olga Szaluś-Jordanow ${ }^{3}$, \\ Marián Várady ${ }^{4}$, Alżbeta Königováa, Marina Spinu ${ }^{5}$, Paweł Górski ${ }^{6}$ Emilia Bagnicka² and Jarosław Kaba ${ }^{1}$
}

\begin{abstract}
Background: Prophylactic anthelmintic treatment with one of three basic classes of anthelmintics (benzimidazoles, macrocyclic lactones and imidazothiazoles) is still the mainstay of control of gastrointestinal nematode infections in small ruminants worldwide. As a consequence, anthelmintic resistance is a serious threat to small ruminant health and production. While the resistance to one class of anthelmintics has already been reported in most of countries, the newly-emerging problem is the resistance to two or even all of classes referred to as multidrug resistance. This study aimed to evidence the presence of multidrug resistance of gastrointestinal nematodes in goats in Poland.

Results: The combination of one in vivo method (fecal egg count reduction test) and two in vitro methods (egg hatch test and larval development test) performed in two goat herds in the southern Poland showed the presence of gastrointestinal nematodes resistant to fenbendazole and ivermectin in both herds. Moreover, in one herd it revealed the development of resistance to the last effective anthelmintic, levamisole, in response to one-year intensive use. Haemonchus contortus was the most prevalent gastrointestinal nematode in samples in which resistance to benzimidazoles and ivermectin was found, whereas Trichostrongylus colubriformis predominated when resistance to levamisole was observed.

Conclusion: This study shows for the first time that multidrug resistance of gastrointestinal nematodes to three basic classes of anthelmintics is already present in goat population in Poland. Moreover, it may indicate that different species or genera of gastrointestinal nematodes are responsible for the resistance to specific anthelmintics.
\end{abstract}

Keywords: Anthelmintic resistance, Benzimidazoles, Gastrointestinal nematodes, Goats, Ivermectin, Levamisole

\section{Background}

Parasitic infections, in particular, those caused by gastrointestinal nematodes (GIN), are one of the main factors responsible for economic losses in goat production around the world. The mainstay of GIN control in goats remains the regular use of anthelmintic drugs of three main classes - benzimidazoles, macrocyclic lactones and

\footnotetext{
* Correspondence: mczopowicz@gmail.com

${ }^{1}$ Division of Veterinary Epidemiology and Economics, Institute of Veterinary Medicine, Warsaw University of Life Sciences-SGGW, Nowoursynowska 159c, 02-776 Warsaw, Poland

Full list of author information is available at the end of the article
}

imidazothiazoles [1, 2]. Nowadays GIN control becomes increasingly problematic due to the emergence of nematodes resistant to one or more classes of anthelmintics. Anthelmintic resistance (AR) has been reported in various GIN in goat herds all over the world, including many European countries. The most prevalent is resistance to benzimidazoles, followed by the resistance to macrocyclic lactones and imidazothiazoles (namely levamisole), with the latter so far only occasionally reported [3]. Anthelmintic resistance distribution appears to correspond to the popularity of anthelmintic classes used in

(c) The Author(s). 2020 Open Access This article is licensed under a Creative Commons Attribution 4.0 International License, which permits use, sharing, adaptation, distribution and reproduction in any medium or format, as long as you give appropriate credit to the original author(s) and the source, provide a link to the Creative Commons licence, and indicate if changes were made. The images or other third party material in this article are included in the article's Creative Commons licence, unless indicated otherwise in a credit line to the material. If material is not included in the article's Creative Commons licence and your intended use is not permitted by statutory regulation or exceeds the permitted use, you will need to obtain permission directly from the copyright holder. To view a copy of this licence, visit http://creativecommons.org/licenses/by/4.0/ The Creative Commons Public Domain Dedication waiver (http://creativecommons.org/publicdomain/zero/1.0/) applies to the data made available in this article, unless otherwise stated in a credit line to the data. 
veterinary practice [3]. Over last two decades, simultaneous resistance of goat parasites to more than one anthelmintic class, referred to as multidrug resistance (MDR), has become an increasing problem in Europe, and thus far has been reported in Denmark [4], France [5], Switzerland [6], Slovakia [7] and the United Kingdom [8].

The first cases of anthelmintic resistance to benzimidazoles and macrocyclic lactones have been described only recently in goats in Poland $[9,10]$. In this article we describe the first case of MDR in goats to all three basic anthelmintic classes.

\section{Results}

\section{Fecal egg count reduction tests (FECRT)}

The first FECRT carried out in the autumn 2017 showed the resistance to FBZ in both herds irrespective of the calculative method used, and the resistance to IVM in herd $\mathrm{A}$ in all three calculative methods while in herd $\mathrm{B}$ in calculative method FECR\%-1 and FECR\%-2. At the same time GIN remained fully susceptible to LEV in both herds. The second FECRT performed after 1 year (autumn 2018) with the use of LEV yielded borderline result in herd A (suspected resistance in method FECR\%-1 and lack of resistance in methods FECR\%-2 and $\mathrm{FECR} \%-3$ ) and confirmed resistance in herd B according to two of three methods (namely method FECR\%-1 and FECR\%-2). The last FECRT performed in herd B after a year (autumn 2019) with the use of LEV provided strong evidence of resistance to LEV in all three calculative methods used (Table 1).

In herd A the main GIN detected before the anthelmintic treatment in both FECRT was Haemonchus contortus (87-99\%), with a very little share of Teladorsagia circumcincta (1-8\%) and Trichostrongylus colubriformis (1-5\%; only in the first FECRT). After the treatment only the number of eggs decreased while composition of GIN remained unchanged regardless of the anthelmintic used.

In herd B in the autumn 2017 the main GIN was $T$. colubriformis, with the smaller share of $H$. contortus and T. circumcincta at nearly the same proportions, and some Oesophagostomum spp. Treatment with FBZ did not affect the composition of GIN (except for Oesophagostomum spp.), suggesting that resistance to this anthelmintic agent was evenly distributed across GIN. Treatment with IVM reduced the share of T. circumcincta and T. colubriformis and rendered $H$. contortus the main GIN, indicating its principal role in the resistance to IVM. On the other hand, treatment with LEV selected GIN population for T. colubriformis, eliminating most of the other GIN (Fig. 1a). This pattern was even more evident in the second and third FECRT, when $T$. colubriformis became the only GIN detectable in fecal samples (Fig. $1 \mathrm{~b}$ and $\mathrm{c}$ ). This indicated that $T$. colubriformis was the main GIN responsible for the resistance to LEV.

\section{Egg hatch test}

Eggs hatching was observed in the wells at and above the established discriminating dose (DD) of TBZ $(0.1 \mu \mathrm{g} /$ $\mathrm{ml}$ ) in both herds. Percentage of hatching of the eggs at DD was 98.5\% (CI 95\%: 95.6, 99.5\%) in herd A, and 96.4\% (CI 95\%: 92.8, 98.2\%) in herd B, which indicated high resistance in both goat herds (Table 2). $\mathrm{ED}_{50}$ was 0.85 (CI 95\%: $0.20,1.49) \mu \mathrm{g} / \mathrm{ml}$ in herd A and 1.08 (CI 95\%: $0.44,1.71) \mu \mathrm{g} / \mathrm{ml}$ in herd $\mathrm{B}$, both values way above the threshold value of $0.1 \mu \mathrm{g} / \mathrm{ml}$.

\section{Larval development test}

Larval development was observed in all wells. In the first LDT performed in June 2018 percentages of larvae developing at the discriminating dose (DD) indicated high resistance to all anthelmintic agents. In the second LDT performed in January 2020 in herd B percentages of larvae developing at the DD indicated high resistance to IVM-AG and LEV and low resistance to TBZ (Table 2). Compared to the first LDT percentage of larvae developing at DD significantly decreased in terms of TBZ $(p<$ $0.001)$ and IVM-AG $(p<0.001)$, whereas it significantly increased in terms of LEV $(p<0.001)$.

In the first LDT in 2018 in both herds mainly $H$. contortus, with the low proportion of Trichostrongylus spp. and Teladorsagia spp. was found in the control wells. In wells containing the three anthelmintics at the DD GIN composition remained unchanged in herd A (Fig. 2a). In herds B GIN composition was also the same in the wells containing TBZ and IVM-AG, while in wells containing LEV Trichostrongylus spp. predominated (Fig. 2b).

In the second LDT, performed in herd B after more than a year of intensive use of LEV (Additional file 2) Trichostrongylus spp. remained the main GIN in control wells, with a small share of $H$. contortus, Teladorsagia spp., and Oesophagostomum spp. In wells with anthelmintics at the DD Trichostrongylus spp. accounted for virtually all GIN that persisted (Fig. 2c).

\section{PCR}

Identification of GIN based on L3 larvae species-specific features was confirmed by the restriction enzyme cleavage [11].

A fragment of the variant of the $1 \beta$-tubulin gene $(250$ bp) associated with resistance of $T$. circumcincta to benzimidazoles was found in goat samples obtained from both herds (Fig. 3, Additional file 4). Moreover, additional fragments were observed which could depend on the geographical origin of the species [12]. Furthermore, fragments of the $1 \beta$-tubulin gene showing the resistance of $H$. contortus to benzimidazoles were also 
Table 1 Results of in vivo faecal egg count reduction tests (FECRT) in goat herds A \& B

\begin{tabular}{|c|c|c|c|c|c|c|c|c|}
\hline \multirow[t]{2}{*}{ Groups } & \multicolumn{4}{|c|}{ FECRT no. 1 - autumn 2017} & \multicolumn{2}{|c|}{ FECRT no. 2 - autumn 2018} & \multicolumn{2}{|c|}{ FECRT no. 3 - autumn 2019} \\
\hline & Control & FBZ & IVM & LEV & Control & LEV & Control & LEV \\
\hline \multicolumn{9}{|l|}{ Herd A } \\
\hline$n$ & 8 & 8 & 8 & 8 & 10 & 10 & - & - \\
\hline $\begin{array}{l}\text { FEC [epg] pre- } \\
\text { treatment }\end{array}$ & & & & & & & - & - \\
\hline mean $\pm S D$ & $1769 \pm 1396$ & $1713 \pm 1259$ & $1731 \pm 1278$ & $1394 \pm 1341$ & $1175 \pm 1212$ & $1940 \pm 1883$ & & \\
\hline median (IQR) & $\begin{array}{l}1225(750- \\
2700)\end{array}$ & $\begin{array}{l}1225(888- \\
2363)\end{array}$ & $\begin{array}{l}1225(950- \\
2338)\end{array}$ & $\begin{array}{l}1025(650- \\
1488)\end{array}$ & $\begin{array}{l}650(550- \\
1500)\end{array}$ & $\begin{array}{l}1350(513- \\
2763)\end{array}$ & & \\
\hline range & $250-4250$ & $400-3750$ & $450-3700$ & $250-4400$ & $150-4300$ & $250-6400$ & & \\
\hline $\begin{array}{l}\text { FEC [epg] post- } \\
\text { treatment }^{\mathrm{a}}\end{array}$ & & & & & & & - & - \\
\hline mean $\pm S D$ & $1606 \pm 1384$ & $1250 \pm 810$ & $1188 \pm 1144$ & $6 \pm 18$ & $815 \pm 632$ & $40 \pm 97$ & & \\
\hline median (IQR) & $\begin{array}{l}925(763- \\
2225)\end{array}$ & $\begin{array}{l}1225(750- \\
2700)\end{array}$ & $\begin{array}{l}750(425- \\
1463)\end{array}$ & $0(0-0)$ & $\begin{array}{l}650(375- \\
1163)\end{array}$ & $0(0-0)$ & & \\
\hline range & $350-4400$ & $250-4250$ & $200-3350$ & $0-50$ & $50-2100$ & $0-300$ & & \\
\hline $\begin{array}{l}\text { FECR\%-1 [\%] (Cl } \\
\text { 95\%) }\end{array}$ & - & $\begin{array}{l}22(-70 \text { to } 64) \\
(\mathrm{R})^{\mathrm{b}}\end{array}$ & $\begin{array}{l}26(-89 \text { to } \\
71)(R)\end{array}$ & $\begin{array}{l}100 \text { (97 to } 100) \\
\text { (ND) }\end{array}$ & - & $\begin{array}{l}95 \text { (75 to } 99) \\
(\mathrm{S})\end{array}$ & - & - \\
\hline FECR\%-2 [\%] & - & $27(\mathrm{R})$ & $31(\mathrm{R})$ & $100(\mathrm{ND})$ & - & 98 (ND) & - & - \\
\hline FECR\%-3 [\%] & - & $20(\mathrm{R})$ & $24(\mathrm{R})$ & 100 (ND) & - & 97 (ND) & - & - \\
\hline \multicolumn{9}{|l|}{ Herd B } \\
\hline$n$ & 6 & 5 & 5 & 5 & 10 & 10 & 22 & 21 \\
\hline \multicolumn{9}{|c|}{ FEC [epg] pre-treatment } \\
\hline mean $\pm S D$ & $3592 \pm 2929$ & $2750 \pm 1065$ & $3080 \pm 1263$ & $3230 \pm 924$ & $4390 \pm 2314$ & $6175 \pm 3365$ & $2355 \pm 1779$ & $2307 \pm 1394$ \\
\hline median (IQR) & $\begin{array}{l}2900(1038- \\
6000)\end{array}$ & $\begin{array}{l}3100(2500- \\
3250)\end{array}$ & $\begin{array}{l}3250(2500- \\
3700)\end{array}$ & $\begin{array}{l}3550(2700- \\
3800)\end{array}$ & $\begin{array}{l}3900(2863- \\
4763)\end{array}$ & $\begin{array}{l}4825(4438- \\
6750)\end{array}$ & $\begin{array}{l}2000(875- \\
3650)\end{array}$ & $\begin{array}{l}2100(1250- \\
3700)\end{array}$ \\
\hline range & $900-7400$ & $1050-3850$ & $1300-4650$ & $1900-4200$ & $2050-10,050$ & $3500-14,750$ & $200-5950$ & $550-4900$ \\
\hline \multicolumn{9}{|c|}{ FEC [epg] post-treatment ${ }^{a}$} \\
\hline mean $\pm S D$ & $2658 \pm 1404$ & $2950 \pm 937$ & $250 \pm 252$ & $70 \pm 157$ & $4980 \pm 2376$ & $665 \pm 652$ & $1911 \pm 1437$ & $1471 \pm 1315$ \\
\hline median (IQR) & $\begin{array}{l}2250(1863- \\
2825)\end{array}$ & $\begin{array}{l}3000(2250- \\
3200)\end{array}$ & $100(50-500)$ & $0(0-0)$ & $\begin{array}{l}4275(4075- \\
5038)\end{array}$ & $400(225-913)$ & $\begin{array}{l}1500(800- \\
2788)\end{array}$ & $\begin{array}{l}1350(600- \\
1950)\end{array}$ \\
\hline range & $1400-5300$ & $1950-4350$ & $50-550$ & $0-350$ & $2250-11,000$ & $0-2000$ & $200-5300$ & $0-5300$ \\
\hline $\begin{array}{l}\text { FECR\%-1 [\%] (Cl } \\
95 \%)\end{array}$ & - & $\begin{array}{l}-11(-88 \text { to } \\
35)(R)\end{array}$ & $\begin{array}{l}91 \text { (74 to } 97 \text { ) } \\
\text { (R) }\end{array}$ & $\begin{array}{l}97(79 \text { to } 100) \\
\text { (ND) }\end{array}$ & - & $\begin{array}{l}87 \text { (73 to } 93 \text { ) } \\
\text { (R) }\end{array}$ & - & $\begin{array}{l}23(-29 \text { to } \\
54)(R)\end{array}$ \\
\hline FECR\%-2 [\%] & - & $-7(\mathrm{R})$ & $92(\mathrm{R})$ & 98 (ND) & - & $89(\mathrm{R})$ & - & $36(\mathrm{R})$ \\
\hline FECR\%-3 [\%] & - & $-45(R)$ & 89 (ND) & 97 (ND) & - & 91 (ND) & - & $21(\mathrm{R})$ \\
\hline
\end{tabular}

$n$ number of animals in the group

FBZ fenbendazole, IVM ivermectin, LEV levamisole

FEC faecal egg count, epg eggs per gram, FECR\% faecal egg count reduction percentage

a 14 days post-treatment in the autumn 2017, 5-7 days post-treatment in the autumn 2018 and 2019

b anthelmintic resistance: $\mathrm{R}$ - confirmed, $\mathrm{S}$ - suspected, ND - not detected

found in the samples from both herds (Fig. 4, Additional file 4). The usefulness of the method of separating the primers into two separate mixtures in the case of $T$. colubriformis and $H$. contortus, proposed by Silvestre and Humbert [12], was confirmed. Detection of the gene fragment associated with the resistance to benzimidazoles was possible by using allele-specific PCR. In the control group, after the electrophoretic separation and visualization, no bands of $250 \mathrm{bp}$ were observed, which confirmed that the larvae from the control group were not resistant to benzimidazoles.

\section{Discussion}

This is the first report of resistance to three main classes of anthelmintic drugs in gastrointestinal nematodes of any animal species in Poland. The resistance to benzimidazoles and macrocyclic lactones had been detected first and levamisole remained the only effective 


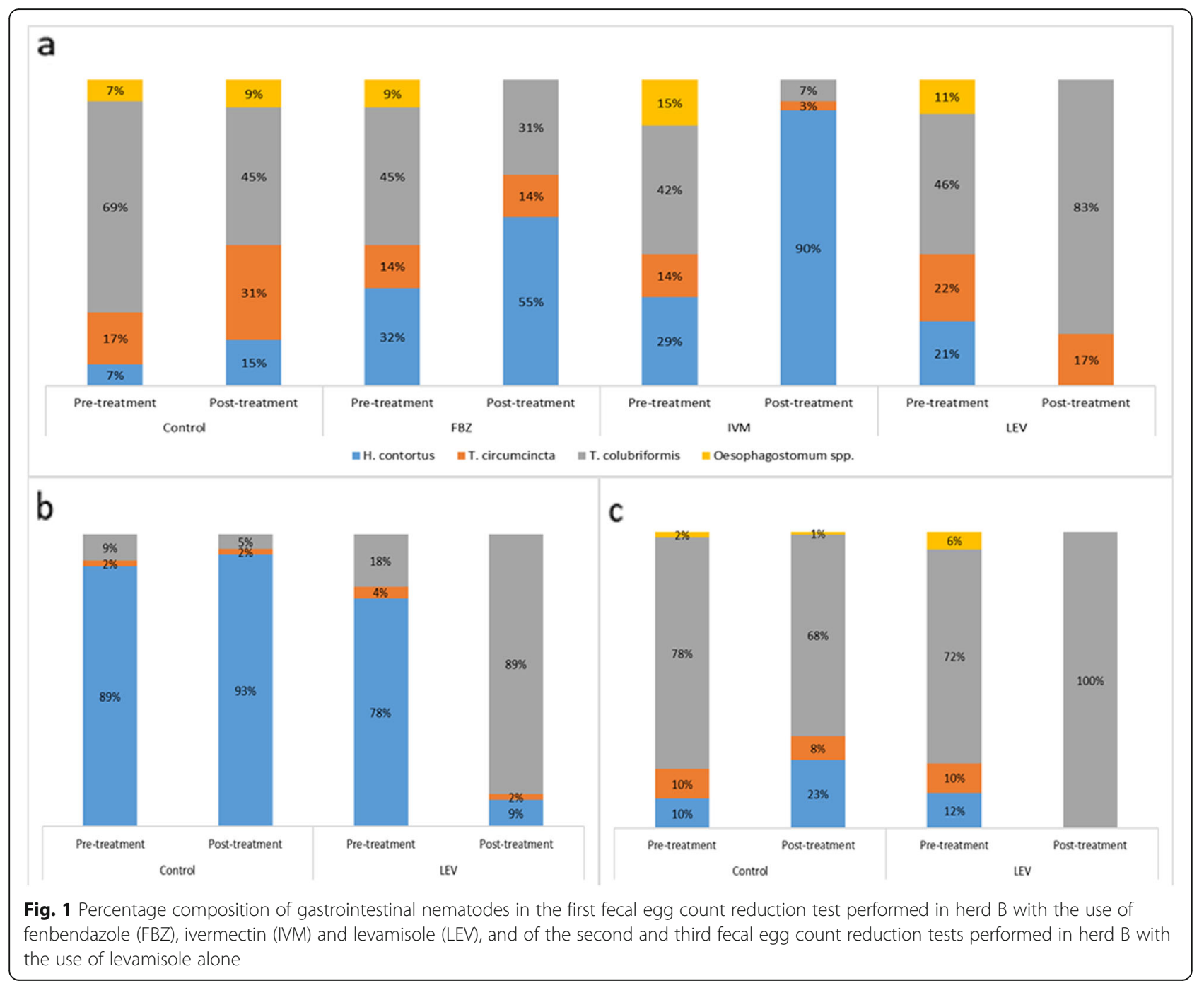

anthelmintic in both herds. The second evaluation of levamisole effectiveness performed after a year of its intensive use showed that the resistance to this anthelmintic agent had also emerged.

We used two groups of commonly approved diagnostic methods to confirm AR. The in vivo method was FECRT, whose results were analysed using three different calculative methods [13] - one classical method comparing FEC between treated and control goats [14, 15], another method which evaluated the reduction of FEC only in treated goats [16] and the most complex method including both the change of FEC in time and between the treated and control goats [17]. Resistance to benzimidazoles and macrocyclic lactones was confirmed in both herds regardless of the calculative method used, as was also the resistance to levamisole in herd B. Two

Table 2 Results of in vitro egg hatch test (EHT) and larval development test (LDT) in goat herds A \& B

\begin{tabular}{|c|c|c|c|c|c|c|c|}
\hline \multirow[t]{2}{*}{$\begin{array}{l}\text { Anthelmintic } \\
\text { agent (DD) }\end{array}$} & \multirow{2}{*}{$\begin{array}{l}\text { EHT } \\
\text { June } 2018 \\
\text { TBZ } \mu \mathrm{g} / \mathrm{ml} \\
(0.10)\end{array}$} & \multicolumn{3}{|l|}{$\begin{array}{l}\text { LDT } \\
\text { June } 2018\end{array}$} & \multicolumn{3}{|l|}{$\begin{array}{l}\text { LDT } \\
\text { January } 2020\end{array}$} \\
\hline & & $\begin{array}{l}\mathrm{TBZ} \mu \mathrm{g} / \mathrm{ml} \\
(0.08)\end{array}$ & $\begin{array}{l}\text { IVM ng/ml } \\
(21.6)\end{array}$ & $\mathrm{LEV} \mu \mathrm{g} / \mathrm{ml}(2.0)$ & $\begin{array}{l}\mathrm{TBZ} \mu \mathrm{g} / \mathrm{ml} \\
(0.08)\end{array}$ & $\begin{array}{l}\text { IVM ng/ml } \\
(21.6)\end{array}$ & $\mathrm{LEV} \mu \mathrm{g} / \mathrm{ml}(2.0)$ \\
\hline & \multicolumn{7}{|c|}{ Corrected percentage (Cl 95\%) of } \\
\hline & hatching eggs at DD & \multicolumn{6}{|c|}{ developing infective L3 larvae at DD } \\
\hline Herd A & $98.5(95.6,99.5)$ & $85.2(81.7,88.1)$ & $99.8(97.8,100)$ & $43.2(36.9,49.7)$ & - & - & - \\
\hline Herd B & $96.4(92.8,98.2)$ & $87.4(82.8,90.9)$ & $93.4(89.6,95.9)$ & $62.2(54.6,69.3)$ & $27.3(21.6,33.9)$ & $56.2(49.3,62.9)$ & $85.6(80.0,89.8)$ \\
\hline
\end{tabular}




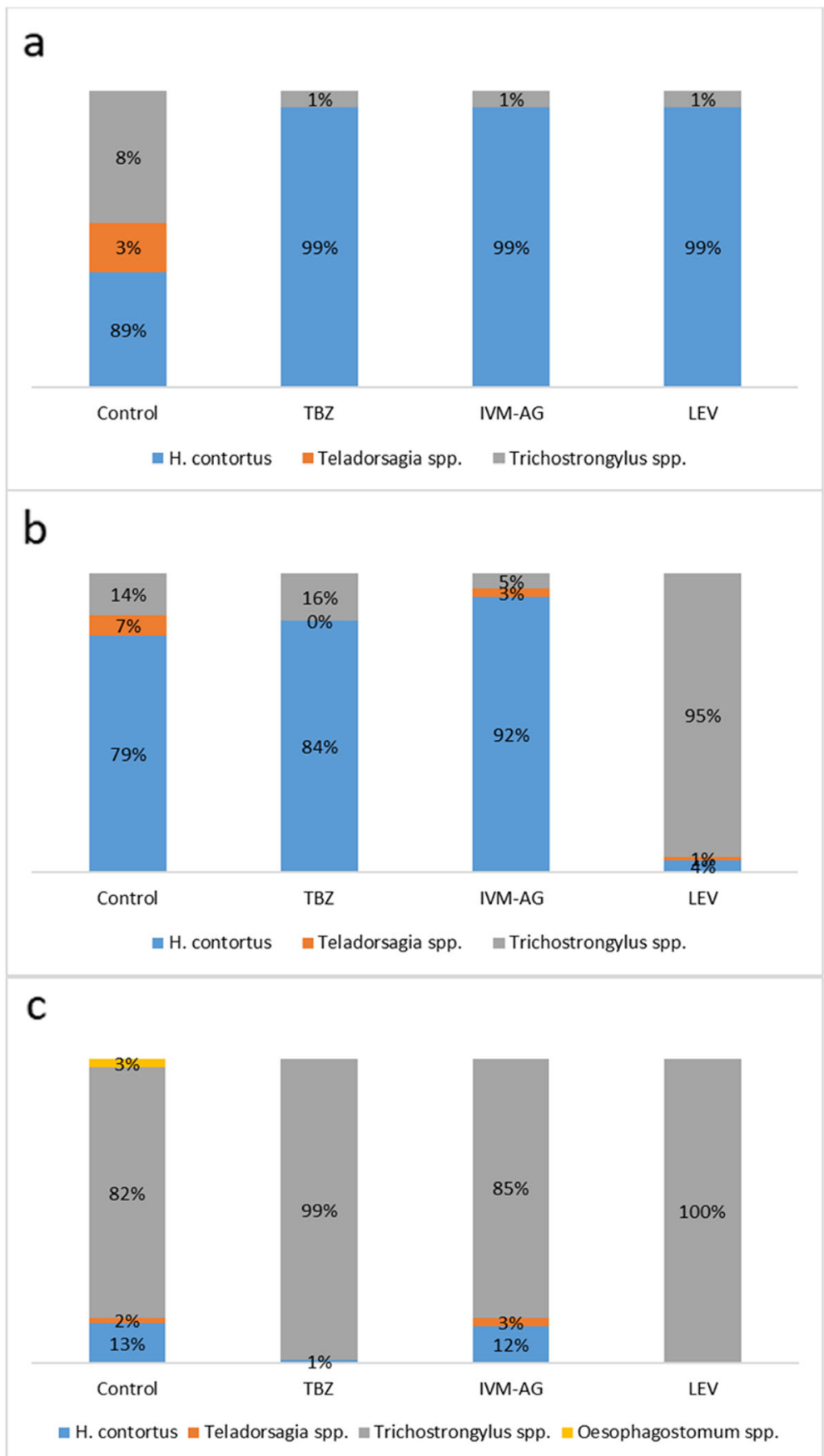

Fig. 2 Percentage composition of gastrointestinal nematodes in control wells and in wells containing thiabendazole (TBZ) at discriminating dose of $0.08 \mu \mathrm{g} / \mathrm{ml}$, ivermectin aglycone (IVM-AG) at discriminating dose of $21.6 \mathrm{ng} / \mathrm{ml}$ and levamisole (LEV) at discriminating dose of $2.0 \mu \mathrm{g} / \mathrm{ml}$ in the first larval development test in herd A (a) and herd B (b), and in the second larval development test in herd B (c)

in vitro methods were used - EHT for detection of resistance to benzimidazoles, and LDT for detection of resistance to all three anthelmintic classes. The interpretation of these tests' results depends on the cut-off value (i.e. discriminating dose, DD) used. We adopted cut-off values commonly accepted in parasitological literature. However, given that the DD of levamisole appears to vary between GIN species with $2.5 \mu \mathrm{g} / \mathrm{ml}$ for H. contortus [18] and $1.0 \mu \mathrm{g} / \mathrm{ml}$ for T. colubriformis [19], results of LDT which we obtained in herd A should be considered as borderline.

In our study we used the combination of the in vivo (FECRT) and the in vitro tests (EHT and LDT), which could increase the sensitivity of the methods for 


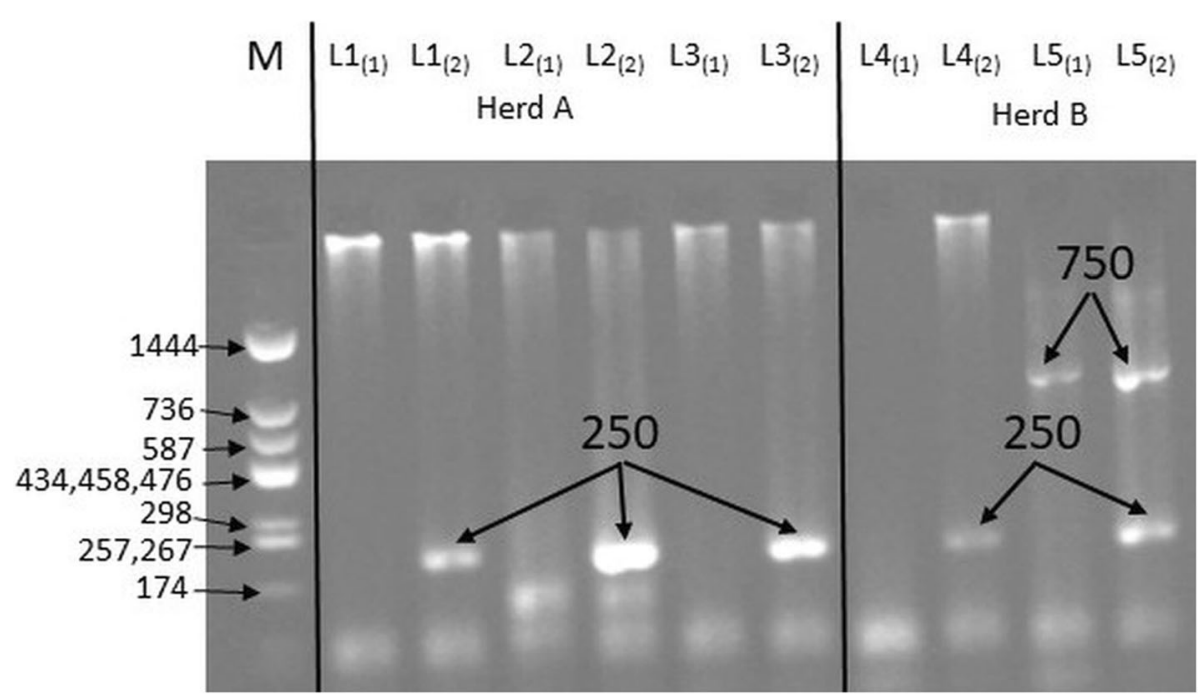

Fig. 3 Polymorphism of the length of restriction fragments of variant- 1 of the $\beta$-tubulin gene indicating the resistance of Trichostrongylus colubriformis to benzimidazoles (cropped gel). M - molecular-weight size marker pUC Mix (11-1444) (A\&A Biotechnology, Gdańsk, Poland), L1-L5 - presence of gene fragment showing resistance for benzimidazoles (T. colubriformis), (1) - the first mixture with three single primers of a given species in ASA-PCR (PC1 - forward primer, PC4 - susceptible allele primer, PC2 - reverse primer), (2) - the second mixture with three single primers of a given species in ASA-PCR (PC1 - forward primer, PC3 - resistant allele primer, PC2 - reverse primer)

detection of AR in the herds. FECRT is able to detect AR when at least $25 \%$ of the population is resistant [20] so its sensitivity is low. Use of FECRT used as the only diagnostic method might result in the underestimation of the AR level on the farms where the resistant alleles are present only in a small proportion of the GIN population. Moreover, the two in vitro tests, EHT and LDT, have the potential to detect a low AR level by using the $\mathrm{ED}_{99} / \mathrm{LC}_{99}$ criterion or a DD [21-23]. Furthermore, the results of Várady et al. [22] also suggest that LDT provides a more accurate quantitative estimate of the level of benzimidazole resistance compared to EHT.

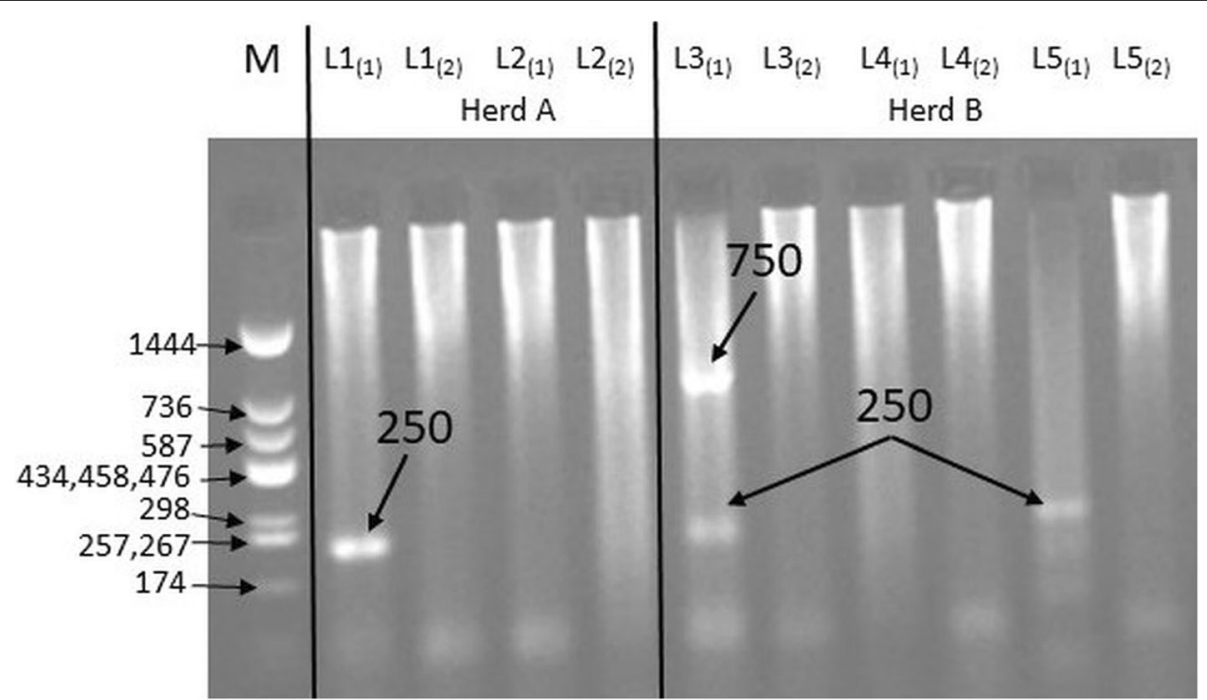

Fig. 4 Polymorphism of the length of restriction fragments of variant- 1 of the $\beta$-tubulin gene indicating the resistance of Haemonchus contortus to benzimidazoles (cropped gel). M - molecular-weight size marker pUC Mix (11-1444) (A\&A Biotechnology, Gdańsk, Poland), L2, L4 - absence of gene fragment (250 bp) showing resistance for benzimidazoles ( $H$. contortus), L1, L3, L5 - presence of gene fragment showing resistance for benzimidazoles (H. contortus), (1) - the first mixture with three single primers of a given species in ASA-PCR (Ph1 - forward primer, Ph4 - susceptible allele primer, Ph2 - reverse primer), (2) - the second mixture with three single primers of a given species in ASA-PCR (Ph1 - forward primer, Ph3 - resistant allele primer, Ph2 - reverse primer) 
In the some cases using the in vitro methods for the detection of AR could be more suitable and sensitive, especially in herds where the resistant alleles are present in the proportion of GIN population [24-26].

The decrease in levamisole effectiveness in herd B was observed after 10 months of exclusive use of this anthelmintic and was first indicated by LDT and then confirmed by FECRT. The quick development of LEV resistance has also been observed in the United States [26], where a decrease in effectiveness occurred after 1 year of extensive use of this anthelmintic. In Europe data on the prevalence of resistance to LEV in goats is limited, however several reports regarding the occurrence of AR to LEV in goat herds have been published in Denmark [4], France [5, 27], and the United Kingdom [28], which may suggest that the resistance to LEV in goats in European countries is still occasional. Our study is the first to reveal the resistance of gastrointestinal nematodes to LEV in Poland. It is interesting that recent reports of goat gastrointestinal nematode resistance to levamisole are from 2009 which may indicate a significant decline in interest in this drug for anthelmintic treatment in goat farms in Europe.

This is the first case of MDR detected in Poland but in our opinion this is just "the tip of the iceberg". This is mainly due to gaps in farmers' and veterinarians' knowledge of factors responsible for the development and spread of AR in ruminant parasites. Goats are known to eliminate various medicines quicker than sheep due to differences in liver metabolism, which results in higher doses needed to ensure anthelmintic efficacy $[29,30]$. Extrapolating doses of anthelmintics from cattle or sheep is a common practice in goat herds in Poland. Moreover, lack of anthelmintic agents registered for goats results in frequent repetition of the same treatment $[31,32]$. Therefore, our results warrant a complex epidemiological countrywide survey on MDR in Poland.

GIN composition observed in our study implies that different nematode species may be more prone to the development of resistance to particular classes of anthelmintics. $H$. contortus seemed to be the only GIN capable of surviving treatment with IVM, while T. colubriformis infection appeared to be the main GIN persisting after the LEV treatment.

Important issue are the origins of MDR in these herds. In both herds a handful of risk factors of AR development were present including high frequency of anthelmintic treatments without anthelmintic class rotation, lack of testing of anthelmintic efficacy, and under-dosing of anthelmintics. Reckless use of anthelmintics appears to be a principal trigger of its development, however, both herds consisted of goats imported from countries in which AR was highly prevalent. Therefore, it is possible that part of GIN with resistant genes had been dragged into these herds along with animals and gave rise to the GIN population with high potential for AR development. Experiences from other countries seem to corroborate this suspicion. The transmission of some resistant parasites between herds via exchange of goats has been described several times in Europe and the United States [6, 23, 33-36]. If this hypothesis was true, goats from these herds would pose a threat to other goats in Poland as a source of multidrug-resistant GIN population. Although, we cannot exclude that the resistant nematodes were dragged into the herds with imported animals, even if it was true, the farmers' reckless behavior served as a trigger for the development of MDR.

\section{Conclusions}

Concluding, our study shows that MDR of GIN parasites is already present in goat population in Poland. Moreover, it indicates that different species/genera may be responsible for the resistance to specific anthelmintic classes $-H$. contortus appears to be the main GIN resistant to benzimidazoles and ivermectin, and T. colubriformis to levamisole. However, this observation needs further investigation and confirmation.

\section{Methods}

\section{Goat herds}

The study was carried out in two related dairy herds (A and B) of pure Anglonubian goats, located in the southern Poland, $275 \mathrm{~km}$ apart from each other.

Herd A was established in 2011 by purchasing several adult goats from various locations in Germany, the Netherlands, the United Kingdom and the United States, from which some other goats have been also bought thereafter. Herd B was set up 3 years later by purchasing several adult goats from herd A. In the time period of interest, spanning 4 years between 2017 and 2020, both herds relied on their own replacement. In 2017 herd A counted approximately 40 adult goats and herd B was twofold smaller. Goats in both herds used to be grazed on their own pastures from April to November, $8 \mathrm{~h}$ a day. Pasture size was 16 ha and 3 ha, respectively, and they were both grass pastures composed mainly of bluegrass, timothy, darnel, fescue, and clover. Grass was harvested once or twice a year to produce hay and once more in the autumn to produce haylage. Apart for the pasture goats had free access to hay at will, and during milking they were given concentrates made of barley, oat and corn. In the winter they were additionally fed on carrots, fodder beet roots, and haylage. Mineral supplements consisted of mineral blocks with selenium. In herd A goats had a wooden building $110 \mathrm{~m}^{2}$ in size, while in the herd B the building was concrete $150 \mathrm{~m}^{2}$ in size. In both buildings gravity ventilation was used. 
In the spring 2017 in both herds a few adult goats and goat kids died and some goats presented with retarded growth, weight loss and diarrhea. Despite regular and frequent deworming (every 2-4 months on average; Additional files 1 and 2) routine parasitological examinations revealed intensive infection with GIN (strongyletype eggs). Both farmers were advised to keep goats indoors to prevent environmental exposure to parasitic infections.

\section{Fecal egg count reduction test (FECRT)}

In the autumn 2017 fecal egg counts (FEC) were determined in all adult goats in both herds and they revealed moderate to severe parasitic infection $(1128 \pm 1234$ eggs per gram (epg) and $3183 \pm 1721 \mathrm{epg}$, respectively). On the basis of these results individual goats were selected for the fecal egg count reduction test (FECRT) so that they satisfied the following criteria: age of at least 6 months, pre-treatment FEC of above $150 \mathrm{epg}$, and no anthelmintic treatment for at least 8 weeks. Thirty six such goats were identified in herd A and 21 in herd $B$.

FECRT was performed according to the guidelines of the World Association for the Advancement of Veterinary Parasitology (W.A.A.V.P.) described by Coles et al. $[14,15]$. Animals were randomly allocated in three treatment groups ( $n=8$ in herd A, $n=5$ in herd B), and one control group ( $n=8$ in herd A, $n=6$ in herd B). Prior to the treatment, animals were weighed on an electronic scale. Goats were treated with recommended doses of fenbendazole (FBZ; $10 \mathrm{mg} / \mathrm{kg}$ p.o., Fenbenat ${ }^{\circ}$ oral powder $40 \mathrm{mg} / \mathrm{g}$ Vetos-farma, Poland), ivermectin (IVM, 0.3 $\mathrm{mg} / \mathrm{kg}$ s.c., Biomectin ${ }^{\otimes} 10 \mathrm{mg} / \mathrm{ml}$ solution for injection, Vetoquinol, Poland), and levamisole (LEV; $12 \mathrm{mg} / \mathrm{kg}$ p.o., Levamol ${ }^{\circ}$ oral powder $80 \mathrm{mg} / \mathrm{g}$, Vetoquinol, Poland) [37]. The medicines were administered by local veterinarians with the owners' assistance. Oral powders were solved in tap water and given directly into the mouth using a syringe so that the entire dose was consumed by each goat. Control groups were left without any treatment for the time of the study. Fecal samples (at least $10 \mathrm{~g}$ of faeces) were collected directly from the rectum on the day of the treatment (day 0), and 14 days after the treatment (day 14). Then, fecal samples were packed in sealed bags, delivered to the laboratory at refrigerator temperature, and examined within $24 \mathrm{~h}$ after collection by the modified McMaster technique with an analytical sensitivity of 50 epg according to W.A.A.V.P. guidelines $[14,15]$. Larval cultures were prepared for each group by mixing $5 \mathrm{~g}$ of faeces collected from each animal on day 0 and on day 14 into one pool per group. After baermannization, a minimum of 100 third-stage larvae (L3) from each pool were identified at the genus/species level following the procedure described by van Wyk and Mayhew [11] and the percentage of each nematode genus/ species was calculated. Differentiation between Trichostrongylus spp. and Teladorsagia spp. was performed after exsheathement of the L3 larvae in 3.5\% sodium hypochlorite solution and comparing specific morphological features of GIN species [38].

In July 2018 the second FECRT was performed in both herds to verify LEV efficacy. Twenty goats, aged at least 6 months and with pre-treatment FEC of above 150 epg, were selected accordingly in each herd and divided into the treatment and control group each counting 10 individuals. The further procedures were consistent with the above description for LEV, except for the fact that fecal samples were collected 5 days after LEV administration, so that W.A.V.V.P. recommendations [15], according to which samples for FECRT for LEV should be collected 3 to 7 days after the treatment, were satisfied.

In December 2019 the third FECRT was performed in herd B to verify LEV efficacy. Forty three goats were selected and divided into the treatment and control group counting 21 and 22 individuals, respectively. All the further procedures were the same as in the second FECRT.

\section{Egg hatch test (EHT)}

For in vitro detection of resistance to benzimidazoles egg hatch test (EHT) was performed in both herds in June 2018 at the Institute of Parasitology of the Slovak Academy of Sciences in Kosice according to the method described by Coles et al. [14, 15]. Pooled fresh fecal samples collected from 15 to 20 randomly selected adult goats were homogenized in tap water and used to completely fill $100 \mathrm{ml}$ bottles to ensure anaerobic conditions as described by Hunt and Taylor [39]. Samples were delivered to the laboratory and processed within $24 \mathrm{~h}$ after collection. Eggs were extracted from samples by sieving through 250, 100 and $25 \mu \mathrm{m}$ sieves, centrifugation, and flotation in Sheather's sugar solution. Then eggs were inspected microscopically to ensure that embryonation had not yet begun, and suspended in deionized water at a concentration of 100 eggs per $\mathrm{ml}$. Eggs suspensions $(1.99 \mathrm{ml})$ were placed in 12 wells of 24-well tissue culture plate (Sarstedt, Germany). A stock solution of thiabendazole (Sigma-Aldrich, Merck, Germany; TBZ) was prepared by dissolving the pure compound in pure dimethyl sulfoxide (SIGMAALDRICH, MERCK, Germany; DMSO) according to von Samson-Himmelstjerna et al. [40]. The final concentration was prepared by adding $10 \mu \mathrm{l}$ of TBZ solution into $1.99 \mathrm{ml}$ of a suspension approximately $100 \mathrm{eggs} / \mathrm{ml}$ in water. The final TBZ concentrations used were 0.05, 0.1, 0.3, 0.5 and $1.0 \mu \mathrm{g} / \mathrm{ml}$. A control (0.5\% DMSO) without anthelmintic was also included in the test. The 24-well plates were sealed to prevent drying and incubated for $48 \mathrm{~h}$ at $27^{\circ} \mathrm{C}$. The incubation was then terminated by adding $10 \mu \mathrm{l}$ of Lugol's iodine to each well. The test was performed with two replicates for each drug concentration. Wells were 
examined microscopically in inverted microscope (Leica DMi1) at 100x magnification and the number of unhatched gastrointestinal eggs and first-stage larvae (L1) in each well were counted and corrected for natural mortality from control wells (corrected percentage inhibition, cPI). The threshold discriminating dose (DD) of TBZ set at $0.1 \mu \mathrm{g} / \mathrm{ml}[14]$.

\section{Larval development test (LDT)}

The larval development (LDT) test was performed in both herds in June 2018 at the Institute of Parasitology of the Slovak Academy of Sciences in Kosice and in herd B in January 2020 at the laboratory of the Division of Veterinary Epidemiology and Economics, Warsaw University of Life Sciences, Poland. Pooled fresh fecal samples were collected from randomly selected 15-20 adult goats from each herd. Storage and extraction of eggs was the same as described above for EHT. Stock solutions of TBZ (Sigma-Aldrich, Merck, Germany), LEV (Sigma-Aldrich, Merck, Germany) and ivermectin aglycone (Tebu-bio, France; IVM-AG) were prepared by dissolving pure drugs in DMSO (Sigma-aldrich, Merck, Germany) and serially diluted 1:2 in DMSO (TBZ, IVM-AG) or in deionized water (LEV) to produce 12 final concentrations ranging from 0.0006 to $1.28 \mu \mathrm{g} /$ $\mathrm{ml}$ for TBZ, from 0.084 to $173.6 \mathrm{ng} / \mathrm{ml}$ for IVM-AG, and from 0.02 to $32 \mu \mathrm{g} / \mathrm{ml}$ for LEV. As it has been demonstrated by Dolinská et al. [21, 41] the use of IVM-AG significantly increased the capacity of the test to distinguish between $H$. contortus strains resistant and susceptible to IVM. Tests were performed according to the procedure described by Hubert and Kerboeuf [42] with further modifications of Várady et al. [43]. Tests were performed in 96 wells cell culture plates (Sarstedt, Germany) with culture medium $(150 \mu \mathrm{l})$ which consisted of: $10 \mu \mathrm{l}$ of either TBZ, IVMAG, LEV or DMSO (control wells) solution, $110 \mu \mathrm{l}$ of deionised water, $20 \mu \mathrm{l}$ of culture medium as described by Hubert and Kerboeuf [44] and $10 \mu \mathrm{l}$ of a suspension (approximately 70-100 eggs) containing amphotericin B (Sigma-Aldrich, Merck, Germany) at a concentration of $5 \mu \mathrm{g} / \mathrm{ml}$, all in one well of the test plate. Tests were performed using 2 replicates at each drug concentration. The plates were sealed to prevent drying and incubated for 7 days at $27^{\circ} \mathrm{C}$. After the incubation period, $10 \mu \mathrm{l}$ od Lugol's solution was added to each well to stop larval development. The unhatched eggs and L1-L3 larvae in each well were counted in an inverted microscope (Leica DMi1 and Olympus CKX53). The L3 larvae in the tested and control wells were identified at the genus/species level following the procedure described by van Wyk and Mayhew [11]. DD for LDT were as follows: TBZ -
$0.08 \mu \mathrm{g} / \mathrm{ml}$ [45], IVM-AG - $21.6 \mathrm{ng} / \mathrm{ml}$ [21] and LEV $-2 \mu \mathrm{g} / \mathrm{ml} \mathrm{[46].} \mathrm{They} \mathrm{were} \mathrm{higher} \mathrm{than} \mathrm{traditionally}$ suggested [15] to avoid misclassification of susceptible GIN.

\section{PCR}

\section{Extraction of DNA}

The L3 larvae obtained from the fecal culture prepared from both herds were used for PCR evaluation. Furthermore, as a control group, L3 larvae obtained from the another herd with no evidence of resistance to benzimidazoles in EHT and LDT were used.

In order to obtain genetic material, the sheath of the larvae was stripped by incubation for $5 \mathrm{~min}$ in a Petri dish containing $4 \mathrm{ml}$ larvae suspension and $180 \mathrm{ml}$ sodium hypochlorite (aqueous solution, about $3.5 \%$ active $\mathrm{Cl}$, Rectapur1, Prolabo, Singapore). For further analysis, they were diluted in deionized water and stored at $-20^{\circ} \mathrm{C}$. The DNA was isolated using commercial Kit Zymo ResearchQuick-DNA ${ }^{\text {tu }}$ Microprep Plus Kit (Irvine, USA) according to the manufacturer's protocol. The quality of DNA was checked by the spectrophotometric NanoDrop1000 (NanoDrop, Waltham, USA) instrument. The absorbance measurements were carried out in $2 \mu \mathrm{l}$ of the sample at $260 / 280 \mathrm{~nm}$ and $260 / 230 \mathrm{~nm}$. For further analysis, only samples with a purity of $1.7-2.0$ were used.

Nested polymerase chain reaction (nested PCR) with restriction fragment length polymorphism (PCR-RFLP) was performed according to the method given by Silvestre and Humbert [12], with modifications resulting from the specificity of the conducted study (thermal profile and a number of cycles used in the PCR).

The two PCRs were performed using primers designed by Silvestre and Humbert [12] on the basis of the first variant of the $\beta$-tubulin gene of two species T. circumcinta and $H$. contortus (Additional file 3 ). In the first PCR the $20 \mu \mathrm{l}$ reaction mixture contained $2 \mu \mathrm{l}$ DNA and $10 \mu \mathrm{l}$ Amplitaq Gold $^{\circ} 360$ Master Mix (Applied Biosystems, Life Technologies, USA), $1 \mu \mathrm{l}$ Pn1 primer, $1 \mu \mathrm{l}$ Pn2 primer, and $6 \mu \mathrm{H}_{2} \mathrm{O}$. PCR was performed in a Takara thermocycler (Kusatsu, Japan) using a thermal profile according to the protocol attached to the Amplitaq Gold ${ }^{\circ}$ 360 Master Mix polymerase. The resulting mixture was used as a DNA template for the next PCR. In the second PCR the $20 \mu \mathrm{l}$ reaction mixture contained $2 \mu \mathrm{l}$ of the mixture obtained in the first PCR, $1 \mu \mathrm{l}$ of Pn3 and Pn4 primers, while the remaining components of the mixture were identical as in the first reaction. The thermal profile was also consistent with the protocol included with the Amplitaq Gold $^{\circ} 360$ Master Mix polymerase (Applied Biosystems, Life Technologies, USA). The final product of the nested PCR was stored at $-20^{\circ} \mathrm{C}$ to use in the further analyses. The restriction fragment length polymorphism (RFLP) method was used to identify 
parasitic species. The product obtained in nested PCR was subjected to the activity of the RsaI restriction enzyme (Nzytech, Lisbon, Portugal) according to the protocol with the cleavage site: $5^{\prime} \ldots \mathrm{GT}^{\wedge} \mathrm{AC} \ldots 3^{\prime}$.

\section{Allele-specific polymerase chain reaction (ASA-PCR)}

In the allele-specific PCR, the mixture obtained in nested PCR was used. In the case of $T$. circumcinta, allele-specific products were amplified using two pairs of primers during one PCR. Two of them showed high complementarity (specific primers), while the other two showed low complementarity to the amplified gene fragments (nonspecific primers). In the case of $H$. contortus and T. colubriformis, two separate PCRs were performed using 3 primers in one mixture (Additional file 3). The reaction mixture $(25 \mu \mathrm{l})$ for the amplification of variant 1 fragment of the $\beta$-tubulin gene $T$. circumcincta contained $10 \mu \mathrm{l}$ of Amplitaq Gold 360 Master Mix (Applied Biosystems, Life Technologies, USA), 4 primers - each $1 \mu \mathrm{l}$ of Pt1, Pt2, Pt3 and Pt4, $9 \mu \mathrm{l} \mathrm{H}_{2} \mathrm{O}$, and $2 \mu \mathrm{l}$ DNA template obtained as a result of the second nested PCR. Mixtures for PCR with DNA of H. contortus and T. colubriformis as two separated mixes (both with three primers) were prepared (Additional file 3). PCR was performed for 35 cycles and the amplification temperature was $60{ }^{\circ} \mathrm{C}$. The obtained fragments of the gene were separated by electrophoresis in a $2 \%$ agarose gel for 1 hour $(55 \mathrm{~V}, 250 \mathrm{~A})$ and then visualized using a GBOX device (Syngene, Bangalore, India). The molecular-weight size marker pUC Mix (11-1444) (A\&A Biotechnology, Gdańsk, Poland) was used. Moreover, both nested and allele-specific PCR were performed for the control group of the GIN larvae showing no AR. Original, full-length gel images showing results of PCR for the length of restriction fragments of variant- 1 of the $\beta$-tubulin gene indicating the resistance of $T$. colubriformis and $H$. contortus to benzimidazoles are presented in Additional file 4.

\section{Data analysis}

Fecal egg count reduction percentage (FECR\%) was calculated using three different methods:

1. Method FECR\%- $1=100 \% \times(1-\mathrm{T} 1 / \mathrm{C} 1)$, according to Coles et al. [14, 15]

2. Method FECR $\%-2=100 \% \times(1-\mathrm{T} 1 / \mathrm{T} 0)$, according to Kochapakdee et al. [16].

3. Method FECR\%-3 $=100 \% \times(1-[\mathrm{T} 1 / \mathrm{T} 0] \times[\mathrm{C} 0 / \mathrm{C} 1])$ according to Dash et al. [17].

T0 and T1 signified the arithmetic mean of FEC (epg) in the treated group on the day of anthelmintic administration and on the last day of the study, respectively. $\mathrm{CO}$ and $\mathrm{C} 1$ signified the arithmetic mean of FEC (epg) on the same days in the control group.

In the method FECR\%-1 AR was considered present when FECR\% was less than 95\% and the lower limit of the CI $95 \%$ was less than $90 \%$. If only one of these conditions was fulfilled AR was suspected. In the method FECR\%-2 AR was indicated by FECR\% of less than $95 \%$ and in the method FECR\%-3 by FECR\% of less than $80 \%$.

Results of EHT and LDT were presented as the percentage of hatching eggs or developing L3 stage infective larvae at DD, respectively. AR was defined as hatching of any eggs (in EHT) or development of any stage L3 infective larvae (in LDT) at the DD of a given anthelmintic. AR was numerically expressed as the percentage of eggs/larvae hatching/developing at DD corrected by the percentage hatching/developing in control wells and was classified as low ( $<30 \%$ development) and high $(\geq 30 \%$ development) [21]. Moreover, TBZ concentrations in EHT were $\log$ transformed and the $\mathrm{S}$-shaped doseresponse curve was fitted by transforming $\mathrm{CPI}$ to their probits, defined as normal equivalent deviates (area under the standard normal curve to the left from the position on the curve corresponding to the probability equal to a given $\mathrm{cPI}$ ) increased by 5 to avoid calculating with negative numbers [47]. The log-probit transformation was used to determine TBZ concentration which inhibits hatching of $50 \%$ of eggs (effective dose, $\mathrm{ED}_{50}$ ) [48]. Benzimidazole resistance was considered as confirmed if the $\mathrm{ED}_{50}$ value was above $0.1 \mu \mathrm{g} / \mathrm{ml}$ [14].

FEC were presented as the arithmetic mean $( \pm$ standard deviation, SD), median (interquartile range, IQR), and range. Percentages were compared between groups with the Pearson chi-square test and 95\% confidence intervals (CI 95\%) were calculated using the Wilson score method [49]. Statistical analysis was performed in TIBCO Statistica 13.3.0 (TIBCO Software Inc., Palo Alto, CA).

\section{Supplementary information}

Supplementary information accompanies this paper at https://doi.org/10. 1186/s12917-020-02501-5.

Additional file 1. Anthelmintic treatment used in the herd $\mathrm{A}$ in years 2014-2019. Detailed data regarding deworming of goats in the herd A during a 5-year period.

Additional file 2. Anthelmintic treatment used in the herd $B$ in years 2014-2019. Detailed data regarding deworming of goats in the herd B during a 5-year period.

Additional file 3 . The sequences of the primers used in the individual polymerase chain reaction mixtures, the length of the product in base pairs, and the access number in the GenBank database. Detailed data regarding primers used in $P C R$.

Additional file 4. Original, full-length gel images presenting results of $P C R$ for the length of restriction fragments of variant- 1 of the $\beta$-tubulin gene indicating the resistance of Trichostrongylus colubriformis (A) and Haemonchus contortus (B) to benzimidazoles. Uncropped gels shown in Fig. 3 (A - Trichostrongylus colubriformis) and Fig. 4 (Haemonchus contortus - B). 


\section{Abbreviations}

AR: Anthelmintic resistance; ASA-PCR: Allele-specific polymerase chain reaction; Cl 95\%: Confidence interval for the level of confidence of 95\%; CPI: Corrected percentage inhibition; DD: Discriminating dose; DMSO: Dimethyl sulfoxide; $\mathrm{ED}_{50}$ : Effective dose; $\mathrm{EHT}$ : Egg hatch test; epg: Eggs per gram; FBZ: Fenbendazole; FEC: Fecal egg count; FECR: Fecal egg count reduction; FECR\%: Fecal egg count reduction percentage; FECR T: Fecal egg count reduction test; GIN: Gastrointestinal nematodes; IVM: Ivermectin; IVM-AG: Ivermectin aglycone; LDT: Larval development test; LEV: Levamisole; MDR: Multidrug resistance; PCR: Polymerase chain reaction; PCR-RFPL: Polymerase chain reaction with restriction fragment length polymorphism; RFLP: Restriction fragment length polymorphism; TBZ: Thiabendazole

\section{Acknowledgments}

Not applicable.

\section{Authors' contributions}

MM, MC and JK designed the study. MM, AM, OS-J, MV, AK performed parasitological tests. EB and EK-G performed PCR. MC performed statistical anaIysis. MM, MC, EB and JK interpreted the results and wrote the manuscript draft. MS, PG, MV and AK reviewed the manuscript. All authors have read and approved the manuscript.

\section{Funding}

The research was financially supported by COST Action COMBAR CA16230 as a Short term scientific mission (STSM) in Institute of Parasitology, Slovak Academy of Sciences, Hlinkova 3, 04001 Košice, Slovakia, during which egg hatch test and larval development test were performed by one of the authors (MM). This article is based upon work from COST Action COMBAR CA16230, supported by COST (European Cooperation in Science and Technology)

The funding body had no role in the design of the study and collection, analysis, and interpretation of data and in writing the manuscript.

\section{Availability of data and materials}

The data sets used and/or analyzed are available from the corresponding author on reasonable request.

\section{Ethics approval and consent to participate}

The study was carried out in accordance with the standards recommended by the EU Directive 2010/63/EU for animal experiments and Good Laboratory Practice and the Act of Polish Parliament of 15 January 2015 on protection of animals used for scientific purposes (Journal of Laws 2015, item 266). All procedures were in line with Polish law regulations.

Permission to collect study samples was granted by participating farmers. The goat farm owners granted informed written consent for participation in the study.

\section{Consent for publication}

Not applicable.

\section{Competing interests}

The authors declare that they have no competing interests.

\section{Author details}

'Division of Veterinary Epidemiology and Economics, Institute of Veterinary Medicine, Warsaw University of Life Sciences-SGGW, Nowoursynowska 159c, 02-776 Warsaw, Poland. ${ }^{2}$ Department of Animal Improvement, Institute of Genetics and Animal Breading, Postępu 36A, Jastrzębiec, 05-555 Magdalenka, Poland. ${ }^{3}$ Department of Small Animal Diseases with Clinic, Institute of Veterinary Medicine, Warsaw University of Life Sciences-SGGW, Nowoursynowska 159c, 02-776 Warsaw, Poland. ${ }^{4}$ Institute of Parasitology, Slovak Academy of Sciences, Hlinkova 3, 04001 Košice, Slovakia. ${ }^{5}$ Department of Infectious Diseases and Preventive Medicine, Law and Ethics, University of Agricultural Sciences and Veterinary Medicine, Calea Mănăștur 3-5, 400372 Cluj-Napoca, Romania. ${ }^{6}$ Division of Parasitology and Invasiology, Department of Preclinical Sciences, Institute of Veterinary Medicine, Warsaw University of Life Sciences-SGGW, Ciszewskiego 8, 02-786 Warsaw, Poland.
Received: 17 April 2020 Accepted: 28 July 2020

Published online: 03 August 2020

\section{References}

1. Holm AS, Sorrensen CRL, Thamsborg SM, Enemark HL. Gastrointestinal nematodes and anthelmintic resistance in Danish goat herds. Parasite. 2014; 21:37..

2. Hoste H, Sotiraki S, de Jesús Torres-Acosta JF. Control of endoparasitic nematode infections in goats. Vet Clin North Am Food Anim Pract. 2011;27: 163-73.

3. Rose $H$, Rinaldi $L$, Bosco A, Mavrot F, de Waal T, Skuce P, Charlier J, Torgerson PR, Hertzberg H, Hendrickx G, Vercruysse J, Morgan ER. Widespread anthelmintic resistance in European farmed ruminants. A systematic review. Vet Rec. 2015;176:546.

4. Maingi N, Bjørn H, Thamsborg SM, Bøgh HO, Nansen P. A survey of anthelmintic resistance in nematode parasites of goats in Denmark. Vet Parasitol. 1996;66:53-66.

5. Chartier C, Soubirac F, Pors I, Silvestre A, Hubert J, Couquet C, Cabaret J. Prevalence of anthelmintic resistance in gastrointestinal nematodes of dairy goats under extensive management conditions in southwestern France. J Helminthol. 2001;75:325-30.

6. Schnyder M, Torgerson PR, Schönmann M, Kohler L, Hertzberg H. Multiple anthelmintic resistance in Haemonchus contortus isolated from south African Boer goats in Switzerland. Vet Parasitol. 2005;128:285-90.

7. Várady M, Papadopoulos E, Dolinská M, Königová A. Anthelmintic resistance in parasites of small ruminants. Sheep versus goats. Helmintologia. 2011;48:137-44.

8. Jackson F, Jackson E, Coop RL. Evidence of multiple anthelmintic resistance in a strain of Teladorsagia circumcincta (Ostertagia circumcincta) isolated from goats in Scotland. Res Vet Sci. 1992;53:371-4.

9. Mickiewicz M, Czopowicz M, Górski P, Kaba J. The first reported case of resistance of gastrointestinal nematodes to benzimidazole anthelmintic in goats in Poland. Ann Parasitol. 2017;63:317-22.

10. Mickiewicz M, Czopowicz M, Moroz A, Szaluś-Jordanow O, Górski P, Várady M, Königová A, Spinu M, Lefkaditis M, Kaba J. Development of resistance to eprinomectin in gastrointestinal nematodes in a goat herd with pre-existing resistance to benzimidazoles. Pol J Vet Sci. 2019;22:753-60.

11. van Wyk JA, Mayhew E. Morphological identification of parasitic nematode infective larvae of small ruminants and cattle. A practical lab guide. Onderstepoort J Vet Res. 2013;80:1-14.

12. Silvestre A, Humbert JF. A molecular tool for species identification and benzimidazole resistance diagnosis in larval communities of small ruminant parasites. Exp Parasitol. 2000;95:271-6.

13. Cabaret J, Berrag B. Faecal egg count reduction test for assessing anthelmintic efficacy. Average versus individually based estimations. Vet Parasitol. 2004;121:105-13.

14. Coles GC, Bauer C, Borgsteede FH, Geerts S, Klei TR, Taylor MA, Waller PJ. World Association for the Advancement of Veterinary Parasitology (W.A.A.V. P.) methods for the detection of anthelmintic resistance in nematodes of veterinary importance. Vet Parasitol. 1992;44:35-44.

15. Coles GC, Jackson F, Pomroy WE, Prichard RK, von Samson-Himmelstjerna G, Silvestre A, Taylor MA, Vercruysse J. The detection of anthelmintic resistance in nematodes of veterinary importance. Vet Parasitol. 2006;136:167-85.

16. Kochapakdee S, Pandey VS, Pralomkarn W, Choldumrongkul S, Ngampongsai W, Lawpetchara A. Anthelmintic resistance in goats in southern Thailand. Vet Rec. 1995;137:124-5.

17. Dash K, Hall E, Barger I. The role of arithmetic and geometricmean worm egg counts in faecal egg count reduction tests and in monitoring strategic drenching programs in sheep. Aus Vet J. 1988;65:66-8.

18. Taylor MA. A larval development test for the detection of anthelmintic resistance in nematodes of sheep. Res Vet Sci. 1990;49:198-202.

19. Coles GC, Tritschler JP, Giordano DJ, Laste NJ, Schmidt AL. Larval development test for detection of anthelmintic resistant nematodes. Res Vet Sci. 1988;45:50-3.

20. Martin PJ, Anderson N, Jarrett RG. Detecting benzimidazole resistance with faecal egg count reduction tests and in vitro assays. Aus Vet J. 1989;66:236-40.

21. Dolinská M, Königová $A$, Letková $V$, Molnár L, Várady M. Detection of ivermectin resistance by a larval development test - Back to the past or step forward? Vet Parasitol. 2013;198:154-8.

22. Várady M, Čudeková P, Čorba J. In vitro detection of benzimidazole resistance in Haemonchus contortus egg hatch test versus larval development test. Vet Parasitol. 2007;149:104-10. 
23. Čudeková P, Várady M, Dolinská M, Königová A. Phenotypic and genotypic characterisation of benzimidazole susceptible and resistant isolates of Haemonchus contortus. Vet Parasitol. 2010;172:155-9.

24. Crook EK, O'Brien DJ, Howell SB, Storey BE, Whitley NC, Burke JM, Kaplan RM. Prevalence of anthelmintic resistance on sheep and goat farms in the mid-Atlantic region and comparison of in vivo and in vitro detection methods. Small Rum Res. 2016;143:89-96.

25. Díez-Baños P, Pedreira J, Sánchez-Andrade R, Francisco I, Suárez JL, Díaz P, Panadero R, Arias M, Painceira A, Paz-Silva A, Morrondo P. Field evaluation for anthelmintic-resistant ovine gastrointestinal nematodes by in vitro and in vivo assays. J Parasitol. 2008:94:925-8.

26. Martinez-Valladares M, Martinez-Perez JM, Robles-Perez D, Cordero-Perez C, Famularo MR, Fernandez-Pato N, Castanon-Ordonez L, Rojo-Vazquez FA. The present status of anthelmintic resistance in gastrointestinal nematode infections of sheep in the northwest of Spain by in vivo and in vitro techniques. Vet Parasitol. 2013;191:177-81

27. Zajac AM, Gipson TA. Multiple anthelmintic resistance in a goat herd. Vet Parasitol. 2000;87:163-72.

28. Paraud C, Kulo A, Pors I, Chartier C. Resistance of goat nematodes to multiple anthelmintics on a farm in France. Vet Rec. 2009;164:563-4.

29. Hong C, Hunt KR, Coles GC. Occurrence of anthelmintic resistant nematodes on sheep farms in England and goat farms in England and Wales. Vet Rec. 1996;139:83-6.

30. Aksit D, Yalinkilinc HS, Sekkin S, Boyacioğlu M, Cirak VY, Ayaz E, Gokbulut C. Comparative pharmacokinetics and bioavailability of albendazole sulfoxide in sheep and goats, and dose dependent plasma disposition in goats. BMC Vet Res. 2015;11:124

31. González Canga A, Sahagún Prieto AM. José Diez Liébana M, Martínez NF, Vega MS, Vieitez JJ. The pharmacokinetics and metabolism of ivermectin in domestic animal species. Vet J. 2009;179:25-37.

32. Conder GA, Campbell WC. Chemotherapy of nematode infections of veterinary importance, with special reference to drug resistance. Adv Parasitol. 1995;35:1-84.

33. Escudero E, Carceles CM, Diaz MS, Sutra JF, Galtier P, Alvinerie M. Pharmacokinetics of moxidectin and doramectin in goats. Res Vet Sci. 1999; 67:177-81.

34. Várady M, Praslička J, Čorba J, Veselej L. Multiple anthelmintic resistance of nematodes in imported goats. Vet Rec. 1993;132:387-8.

35. Borgsteede FH, Pekelder JJ, Dercksen DP. Anthelmintic resistant nematodes in goats in the Netherlands. Vet Parasitol. 1996;65:83-7.

36. Howell SB, Burke JM, Miller JE, Terrill TH, Valencia E, Williams MJ, Williamson LH, Zajac AM, Kaplan RM. Prevalence of anthelmintic resistance on sheep and goat farms in the southeastern United States. J Anim Vet Med Assoc. 2008;233:1913-9.

37. Matthews J. Diseases of the Goat. 3rd ed. Oxford: Wiley-Blackwell; 2009.

38. McMurtry LW, Donaghy MJ, Vlassoff A, Douch PGC. Distinguishing morphological features of the third larval stage of ovine Trichostrongylus spp. Vet Parasitol. 2000;90:73-81.

39. Hunt KR, Taylor MA. Use of the egg hatch assay on sheep faecal samples for the detection of benzimidazole resistant nematodes. Vet Rec. 1989;125:153-4

40. von Samson-Himmelstjerna G, Coles GC, Jackson F, Bauer C, Borgsteede F, Cirak VY, Demeler J, Donnan A, Dorny P, Epe C, Harder A, Höglund J, Kaminsky R, Kerboeuf D, Küttler U, Papadopoulos E, Posedi J, Small J, Várady M, Vercruysse J, Wirtherle N. Standardization of the egg hatch test for the detection of benzimidazole resistance in parasitic nematodes. Parasitol Res. 2009;105:825-34

41. Dolinská M, Königová A, Várady M. Is the micro-agar larval development test reliable enough to detect ivermectin resistance? Parasitol Res. 2012;111: 2201-4.

42. Hubert J, Kerboeuf D. A microlarval development assay for the detection of anthelmintic resistance in sheep nematodes. Vet Rec. 1992;130:442-6.

43. Várady $M$, Bjørn $H$, Nansen P. In vitro characterization of anthelmintic susceptibility of field isolates of the pig nodular worm Oesophagostomum sp. susceptible or resistant to various anthelmintics. Int J Parasitol. 1996;26: 733-40.

44. Hubert J, Kerboeuf D. A new method for culture of larvae used in diagnosis of ruminant gastrointestinal strongylosis: comparison with fecal cultures. Can J Comp Med. 1984;48:63-71.

45. Babják M, Konigöva A, Urda-Dolinská M, Vadlejch J, Varády M. Anthelmintic resistance in goat herds - in vivo versus in vitro detection methods. Vet Parasitol. 2018;254:10-4.
46. Kupčinskas T, Stadalienè I, Šarkūnas M, Petkevičius S. Anthelmintic resistance in sheep farms in Lithuania detected by in vitro micro-agar larval development test. Vet Med Zoot. 2015;72:21-3.

47. Healy MJ. Estimating LD50s without a computer. Parasitol Today. 1988:4:25-7.

48. Akhter N, Arijo AG, Phulan MS, Zafar I. In vivo and in vitro studies on the efficacy of anthelmintics against Haemonchus contortus in goats. Pak Vet J. 2014:34:329-32.

49. Altman D, Machin D, Bryant T, Gardner M. Statistics with confidence: confidence intervals and statistical guidelines. 2nd ed. Bristol: BMJ Books; 2000

\section{Publisher's Note}

Springer Nature remains neutral with regard to jurisdictional claims in published maps and institutional affiliations.
Ready to submit your research? Choose BMC and benefit from:

- fast, convenient online submission

- thorough peer review by experienced researchers in your field

- rapid publication on acceptance

- support for research data, including large and complex data types

- gold Open Access which fosters wider collaboration and increased citations

- maximum visibility for your research: over $100 \mathrm{M}$ website views per year

At BMC, research is always in progress.

Learn more biomedcentral.com/submissions 